PREMIO DE ARTÍCULOS JURÍDICOS «GARCÍA GOYENA»

DECIMOSEXTA CONVOCATORIA (CURSO 2016-2017) 

REVISTA DE DERECHO UNED, NÚM. 21, 2017

\section{LA REFORMA DE LOS REGLAMENTOS DE ARBITRAJE Y SU IMPACTO SOBRE EL CONVENIO ARBITRAL}

\section{THE AMENDMENT OF ARBITRATION RULES AND ITS IMPACT ON THE ARBITRATION AGREEMENT}

Premio de Artículos Jurídicos García Goyena

XVI Edición

Primer premio

"Reforma de las instituciones, reforma del Derecho»

\section{LUIS GÓMEZ-IGLESIAS RosóN}

Resumen: Los reglamentos de arbitraje son objeto de frecuentes reformas. En ocasiones ocurre que esas modificaciones se producen entre el momento de la perfección del convenio arbitral y el inicio del procedimiento arbitral. En tales casos se plantea la duda sobre la aplicabilidad o no en ese procedimiento de las nuevas disposiciones reglamentarias, que no existían cuando se perfeccionó el convenio arbitral y que, por tanto, las partes no podían conocer cuando se remitieron al reglamento arbitral en cuestión. El presente trabajo pretende plantear este debate y obtener conclusiones prácticas para cada uno de los operadores jurídicos implicados en el campo del arbitraje.

Abstract: Arbitration rules are frequently amended. It is sometimes the case that such modifications take place during the time between the signing of the arbitration agreement and the beginning of the arbitration procedure. In such cases, the question arises as to the applicability of the new set of rules, which did not exist when the arbitration agreement was signed and which, therefore, the parties were not aware of when they decided to adhere to that particular set of ar- 
bitration rules. This paper addresses this debate and draws conclusions for each of the actors in the arbitration arena.

Palabras clave: arbitraje, reglamento, reforma.

Keywords: arbitration, arbitration rules, amendment.

Sumario: 1. Introducción y planteamiento; 2. Análisis comparado sobre el impacto de la reforma de un reglamento de arbitraje en el convenio arbitral; 2.1 Estudio comparado por jurisdicciones; 2.1.1 Estados Unidos; 2.1.2 Francia; 2.1.3 Inglaterra; 2.1.4 Italia; 2.1.5 Suiza; 2.1.6 Singapur; 2.2 La tendencia comparada hacia una interpretación dinámica del convenio arbitral; 3. La reforma de los reglamentos de arbitraje y su impacto sobre el convenio arbitral en España; 3.1 El convenio arbitral con remisión a un reglamento como negocio jurídico per relationem; 3.2 El convenio arbitral con remisión a un reglamento como "contrato normativo»; 4. Conclusiones.

\section{INTRODUCCIÓN Y PLANTEAMIENTO}

La autonomía de la voluntad es la piedra angular del arbitraje. Su misma existencia depende del expreso sometimiento de las partes a arbitraje de todas o algunas de las controversias que hayan surgido o puedan surgir respecto de una determinada relación jurídica. Pero la influencia de la autonomía de las partes no se agota con la sumisión a arbitraje. Una de las principales manifestaciones de esa soberanía negocial es, tal y como recoge el artículo 25.1 de la Ley 60/2003, de Arbitraje (en adelante, «LA»), la posibilidad de que las partes puedan "convenir libremente el procedimiento al que se hayan de ajustar los árbitros en sus actuaciones». Se reconoce así a las partes plena libertad para configurar el procedimiento arbitral, con el único límite de la imperativa sujeción a los principios de igualdad, audiencia y contradicción (art. 24.1 LA).

Dentro de las posibilidades que a tal fin se ofrecen a las partes, el artículo 4.1.b) de la LA prevé la posibilidad de que el contenido del convenio arbitral se integre con «las disposiciones del reglamento de arbitraje al que las partes se hayan sometido». Se trata de una práctica sin duda mayoritaria, tanto en el arbitraje institucional, en el que las partes se remiten al reglamento de la correspondiente institución arbitral, como en el arbitraje ad hoc, donde el convenio arbitral incorpora por referencia un reglamento modelo no vinculado con ningún 
centro de arbitraje ${ }^{1}$. Las cuestiones que se plantean en el presente trabajo son, por tanto, predicables tanto del arbitraje institucional como del arbitraje ad hoc reglamentado ${ }^{2}$.

Con frecuencia, los reglamentos de arbitraje son reformados para mejorar sus disposiciones y adaptarlas a las últimas tendencias en el campo del arbitraje ${ }^{3}$. En ocasiones ocurre que esas modificaciones se producen entre el momento de la perfección consensual del convenio arbitral -normalmente en forma de cláusula compromisoria inserta en un contrato- y el momento en que surge la disputa y se inicia el procedimiento arbitral. Surge entonces la cuestión acerca de la aplicabilidad en ese procedimiento de las nuevas disposiciones reglamentarias, que no existían cuando las partes perfeccionaron el convenio arbitral y que, por tanto, no podían conocer cuando se remitieron al reglamento arbitral en cuestión.

Así, cuando las partes no han especificado a qué versión del reglamento se someten, se plantea la duda de cuál de ellas resultará aplicable al procedimiento arbitral: bien aquella en vigor al tiempo en que se celebró el convenio arbitral -considerando que las partes realizan

${ }^{1}$ El reglamento modelo por antonomasia empleado en los arbitrajes ad hoc es el Reglamento de Arbitraje de la Comisión de las Naciones Unidas para el Derecho Mercantil Internacional («CNUDMI»). Como se ha dicho, «los operadores de las transacciones mercantiles internacionales se refieren a él cada vez con mayor frecuencia en sus cláusulas compromisorias o en los acuerdos de arbitraje» (FERNÁNDEZ-RozAS, José Carlos, "Luces y sombras del arbitraje institucional en los litigios transnacionales", Revista de la Corte Española de Arbitraje, vol. XXIII, 2008, pág. 82).

${ }^{2}$ Sobre la distinción entre arbitraje administrado y arbitraje reglamentado, es clara la Sentencia de la Audiencia Provincial de Madrid (Sección 11. ${ }^{\text {a }}$ ) de 27 de diciembre de 2011 (Roj: SAP M 19365/2011): «las partes pueden someterse a un reglamento arbitral sin necesidad de encomendar la administración del arbitraje a ninguna entidad, pudiendo decidir en el convenio arbitral o en otro acuerdo posterior, que los litigios se sometan a arbitraje 'de acuerdo' con un determinado Reglamento; en este caso, no existirá arbitraje administrado, sino 'reglamentado', y las disposiciones del Reglamento integrarán la voluntad de las partes. Cabe que el arbitraje sea administrado y, en este caso, el reglamento al que las partes se hayan sometido será el de la entidad a la que hayan encomendado esa función, pero cabe también, como hemos dicho, que las partes se sometan simplemente a un reglamento arbitral». En este sentido, la Exposición de Motivos de la LA precisa que «las partes pueden someterse a un concreto reglamento sin encomendar la administración del arbitraje a una institución, en cuyo caso el reglamento arbitral también integra la voluntad de las partes».

${ }^{3}$ La Sección Primera del Código de Buenas Prácticas Arbitrales del Club Español del Arbitraje de diciembre de 2005 (disponible en www.clubarbitraje.com) establece que «[l]as instituciones arbitrales administrarán sus procedimientos sobre la base de reglamentos actualizados que se adapten a las necesidades del tráfico y reflejen la evolución de las prácticas arbitrales». En el mismo sentido, se ha destacado que los reglamentos de arbitraje son «frecuentemente renovados» $\mathrm{y}$ "perfeccionados con la experiencia» (FERNÁNDEZ-RozAs, José Carlos, op. cit. supra n. 1, págs. 82 y 83). 
un reenvío «estático» fijado en la fecha del convenio-, o bien aquella vigente cuando se inicia el procedimiento -considerando que el convenio arbitral realiza una remisión «dinámica»-4 .

La cuestión es ciertamente relevante, pues la aplicación de un reglamento que no se ajuste al acuerdo de las partes podría suponer en última instancia la anulación o falta de reconocimiento del laudo que se dicte en el procedimiento arbitral. El artículo 41.1.d) de la LA establece que el laudo podrá ser anulado cuando el procedimiento arbitral no se ajuste al acuerdo de las partes ${ }^{5}$. En el mismo sentido, la oposición del procedimiento arbitral al acuerdo de la partes constituye una causa para denegar el reconocimiento y la ejecución de un laudo arbitral extranjero conforme el artículo V.1.d de la Convención de Nueva York sobre el Reconocimiento y la Ejecución de las Sentencias Arbitrales Extranjeras ( $\mathrm{CNY} »)^{6}$.

Pese a su notable importancia y a diferencia de lo que ocurre en otros países, esta cuestión ha merecido escasa atención por la doctrina española ${ }^{7}$. El presente trabajo se propone aclarar, a partir de un

${ }^{4}$ Con carácter general, los reglamentos de arbitraje extienden su ámbito de aplicación temporal a todos los procedimientos arbitrales que comiencen a partir de la entrada en vigor de la reforma, con independencia de la fecha en que se haya suscrito el convenio arbitral. Por ejemplo, la disposición transitoria del Reglamento Modelo del Club Español del Arbitraje establece que se aplicará «a todo arbitraje cuya solicitud haya sido presentada a partir del día de su entrada en vigor» (Sección Segunda del Código de Buenas Prácticas Arbitrales del Club Español del Arbitraje de octubre de 2008, disponible en www.clubarbitraje.com). Existen, no obstante, algunos reglamentos que establecen la aplicación de la versión vigente al momento de celebrarse el convenio arbitral. En este último caso, no se planteará el conflicto temporal que es objeto del presente estudio.

${ }^{5}$ Según el artículo 41.1.d de la LA, «[e]l laudo sólo podrá ser anulado cuando la parte que solicita la anulación alegue y pruebe: (...) d) Que la designación de los árbitros o el procedimiento arbitral no se han ajustado al acuerdo entre las partes, salvo que dicho acuerdo fuera contrario a una norma imperativa de esta Ley, o, a falta de dicho acuerdo, que no se han ajustado a esta ley».

${ }^{6}$ Conforme al artículo V.1.d de la CNY, «[s]ólo se podrá denegar el reconocimiento y la ejecución de la sentencia, a instancia de la parte contra la cual es invocada, si esta parte prueba ante la autoridad competente del país en que se pide el reconocimiento y la ejecución: (...) d) Que la constitución del tribunal arbitral o el procedimiento arbitral no se han ajustado al acuerdo celebrado entre las partes o, en defecto de tal acuerdo, que la constitución del tribunal arbitral o el procedimiento arbitral no se han ajustado a la ley del país donde se ha efectuado el arbitraje».

${ }^{7}$ Sí plantea esta cuestión el profesor Antonio HERNÁNDEZ-GIL ÁlLVAREZ-CIENFUEGos, en De Martín Muñoz, Alberto y Hierro Anibarro, Santiago (coords.), Comentario a la Ley de Arbitraje, Marcial Pons 2006, págs. 186 y 187. También, más recientemente, Juan Carlos Calvo Corvella, en Ruiz Risueño, Francisco y Fernández Rozas, José Carlos (coords.), Comentarios al Reglamento de la Corte Civil y Mercantil de Arbitraje (2015), CIMA 2016, págs. 91 y 92. Desde una perspectiva práctica, la Sección Segunda del Código de Buenas Prácticas Arbitrales del Club Español del Arbitraje de octu- 
análisis comparado y analizando la lex arbitri española, cuál es el reglamento aplicable en esos casos.

\section{ANÁLISIS COMPARADO SOBRE EL IMPACTO DE LA REFORMA DE UN REGLAMENTO DE ARBITRAJE EN EL CONVENIO ARBITRAL}

\subsection{Estudio comparado por jurisdicciones}

Antes de abordar el estudio de la lex arbitri española en esta materia, conviene analizar el estado de la cuestión en diferentes jurisdicciones. Este análisis comparado es útil por cuanto los razonamientos empleados por la práctica judicial extranjera son, en buena medida, trasladables al ordenamiento jurídico español.

Como veremos, la experiencia comparada muestra una mayoritaria aceptación de la concepción dinámica de las referencias del convenio arbitral a los reglamentos de arbitraje ${ }^{8}$. Esta práctica ha servido a la doctrina para formular una regla general en el arbitraje internacional según la cual, salvo pacto en contrario de las partes, el reglamento aplicable es aquel en vigor en el momento del procedimiento arbitral $^{9}$. No obstante, esta postura no es unánime y algunos tribunales nacionales han establecido ciertos matices.

bre de 2008 (disponible en www.clubarbitraje.com) recomienda a las partes que precisen en su convenio arbitral la concreta versión del reglamento aplicable: «Cuando la administración del arbitraje se encomiende a alguna institución arbitral, la cláusula arbitral deberá incluir la referencia a que el Reglamento de la Corte aplicable sea el vigente en el momento de iniciar el arbitraje, para evitar dudas sobre el Reglamento aplicable cuando éste haya sido modificado entre el momento de la firma de la cláusula arbitral y el inicio del procedimiento».

${ }^{8}$ Greenberg, Simon y Mange, Flavia, «Institutional and Ad Hoc Perspectives on the Temporal Conflict of Arbitral Rules», Journal of International Arbitration, Kluwer Law International 2010, Volumen 27, pág. 208: «[T]here is overwhelming consensus that parties are assumed to prefer the most recent and appropriate version of the rules that correspond to their chosen institution or organization. Indeed, it would be difficult for a party in good faith to deny that, at the time it entered into an arbitration agreement selecting the rules of a given institution, it would not have wanted the very latest and best suited rules of that institution to apply in the event of a dispute. If parties intend to "freeze» arbitration rules to the version applicable when they make an arbitration agreement, they should say so expressly. If not, they will be presumed to have chosen the latest and most appropriate rules of the chosen institution».

${ }_{9}^{9}$ SHACKELFORD, Elisabeth, «Party Autonomy and regional Harmonization of Rules in International Commercial Arbitration», University of Pittsburgh Law Review, Volumen 67, 2006, pág. 903. 


\subsubsection{Estados Unidos}

En Estados Unidos, la cuestión objeto del presente estudio fue abordada por primera vez en el caso Mobil Oil Indonesia c. Asamera Oil (1977) ${ }^{10}$. En 1968 las partes suscribieron un contrato con una cláusula de arbitraje, según la cual cualquier disputa relacionada con el contrato se resolvería «mediante arbitraje de conformidad con el Reglamento de la Cámara de Comercio Internacional» ${ }^{11}$. En el procedimiento arbitral, la parte demandada sostuvo que eran aplicables las disposiciones reglamentarias de 1955, vigentes cuando se firmó el contrato en 1968, mientras que la demandante defendía que debía aplicarse la nueva versión de 1975, en vigor al tiempo del inicio del procedimiento. El tribunal arbitral dictó un laudo por mayoría estableciendo que se aplicaría la versión de 1975, al considerar-debido a los términos genéricos de la cláusula- que las partes no habían atribuido importancia a ninguna versión del reglamento en particular, por lo que la intención de las partes era someterse al reglamento de la Cámara de Comercio Internacional ( $(\mathrm{CCI} »)$ vigente en cada momento ${ }^{12}$. Este razonamiento se encontraría en línea con el principio general conforme al cual las normas procesales aplicables son aquellas vigentes al tiempo en que surgen las cuestiones procedimentales ${ }^{13}$. Mobil Oil Indonesia promovió entonces la anulación del laudo interlocutorio, que fue estimada en primera instancia. La Corte de Apelaciones de Nueva York, sin embargo, ordenó revocar esa resolución y confirmar la validez del laudo, entendiendo que los árbitros

${ }^{10}$ Mobil Oil Indonesia Inc. v. Asamera Oil (Indonesia) Ltd. et al., 56 A. D.2d 339 (N. Y. App. Div. 1977); y Mobil Oil Indonesia Inc. v. Asamera Oil (Indonesia) Ltd. et al., 43 N. Y.2d 276, 401 N. Y. S.2d 186 (1977).

${ }^{11}$ "Any dispute arising out of or relating to this Agreement shall be settled by arbitration in accordance with the Rules of the International Chamber of Commerce».

${ }^{12}$ Laudo interlocutorio de 30 de marzo de 1976 dictado en el caso núm. 2671 de la CCI: «[The parties'] reference in the arbitration clause to the «Rules of the International Chamber of Commerce» at large is conclusive evidence that they attached no importance to any particular «vintage» of the Rules and that they must be deemed to have intended that, if and when a dispute arose and was referred to arbitration, the proceedings would be governed by the ICC Rules as they were from time to time, not excluding the possibility that different sets of Rules might be in force at the commencement and at a later stage of the arbitration».

${ }^{13}$ Según indica la resolución de la Appellate Division of the Supreme Court of New York (vid. supra n. 10): «On March 30, 1976 the arbitrators, again by a majority vote, ruled in an interlocutory award that the 1975 Rules were applicable. They concluded the parties intended to refer to the Rules as they were from time to time and that the general principle, as well as New York law, is to apply procedural rules as they exist at the time the procedural issues arise». 
habían alcanzado una conclusión razonable sobre qué versión del reglamento resultaba aplicable ${ }^{14}$.

\subsubsection{Francia}

La solución adoptada por los tribunales franceses en el caso Société SNF c. Chambre de commerce internationale (2009) ${ }^{15}$ parece ser la contraria.

En 1993, SNF y Cytec suscribieron un contrato de suministro en el que incluyeron una cláusula de sumisión a arbitraje de la CCI con sede en Bélgica. En ese momento, el reglamento de la CCI en vigor era el de 1988. En el año 2000 surgió un conflicto entre las partes, que iniciaron un procedimiento arbitral. Para entonces, la versión vigente del reglamento de la CCI era la de 1998, que fue la empleada en el procedimiento arbitral. Tras ese procedimiento, SNF interpuso demanda en París contra la propia CCI sobre la base del incumplimiento de su propio reglamento, que supuso un retraso del procedimiento y unos costes excesivos. La discusión en este procedimiento se centró en determinar qué reglamento era el aplicable al procedimiento arbitral que había enfrentado a SNF y Cytec, pues, a diferencia de la versión de 1988, el reglamento de 1998 contenía una disposición de exoneración de responsabilidad de la institución arbitral. La demanda fue desestimada en primera instancia al considerar que, salvo pacto en contrario de las partes, la versión aplicable era la vigente en el momento en que se presentó la solicitud de arbitraje frente a la $\mathrm{CCI}^{16}$. La Corte de Apelación de París, sin embargo, consideró que la versión aplicable debía ser la de 1988 porque el reglamento constituye una «oferta permanente» al público realizada por la CCI, que fue aceptada por las partes cuando suscribieron el convenio arbitral en $1993^{17}$. No

${ }^{14}$ Ibid.: «Did the parties agree to arbitrate and did the arbitrators make a rational determination of which procedural rules to apply? As the answer to both portions of the question is in the affirmative, it was improper for the court below to impose its judgment in the place and stead of the arbitrators".

${ }^{15}$ Cour d'appel de Paris, 22 de enero de 2009 (Société SNF c. Chambre de commerce internationale).

${ }^{16}$ Tribunal de Grande Instance de Paris (1e ch.), 10 de octubre de 2007 (Société SNF c. Chambre de commerce internationale): "Sauf conventions contraires entre les parties, inexistantes en l'occurrence, le règlement applicable est celui qui était en vigueur à la date du début de l'arbitrage, soit le Règlement de 1998».

${ }^{17}$ Cour d'appel de Paris, 22 de enero de 2009 (Société SNF c. Chambre de commerce internationale): «Considérant que la CCI par l'intermédiaire de la Cour Internationale d'Arbitrage est en offre permanente de contracter, qui est matérialisé par le règlement d'arbitrage qu'elle publie et donc tout intéressé peut accepter les effets; qu'en 
obstante, la Cour aplicó finalmente el reglamento de 1998 porque la CCI había administrado el arbitraje conforme a esa versión de las normas y las partes lo aceptaron mediante la firma del acta de misión ${ }^{18}$.

Así, en Francia se ha concebido el convenio arbitral con remisión a un reglamento como un reenvío estático. Debe tenerse en cuenta, no obstante, que la cuestión analizada en este caso no era pura y simplemente la aplicabilidad de un reglamento a un procedimiento arbitral, sino la determinación del contenido obligacional de la relación contractual entre las partes y la institución arbitral.

\subsubsection{Inglaterra}

En Inglaterra, en cambio, una consolidada línea jurisprudencial ha establecido que, cuando una cláusula de arbitraje se refiere a un reglamento, existe una presunción iuris tantum de que las partes se remiten al reglamento vigente al inicio del procedimiento arbitral.

En el caso Offshore International v. Banco Central (1976), surgió un conflicto sobre la aplicación del reglamento de la CCI de 1955 o de 1975. El convenio arbitral se había suscrito cuando se encontraba vigente la versión de 1955 y el procedimiento había comenzado tan solo un mes después de la entrada en vigor del texto reformado. El juez, analizando la literalidad de la cláusula de arbitraje, consideró que si las partes hubieran querido establecer que el reglamento de 1955 fuera el reglamento aplicable a cualquier arbitraje que tuviera lugar entre ellas, podrían haberlo establecido y que, al no haberlo hecho, debe entenderse que el reglamento de 1975 es el aplicable ${ }^{19}$.

La sentencia dictada en el caso Bunge c. Kruse (1979) es el primera de una serie de resoluciones dictadas a raíz de una reforma del reglamento de arbitraje de la Asociación de Comercio de Granos y Piensos (GAFTA, por sus siglas en inglés) que limitaba el tiempo de que disponían las partes para iniciar el arbitraje. La sentencia contiene una

l'occurrence au moment où l'offre émise par la CCI a été acceptée en 1993 par les sociétés SNF et CYTEC, ces dernières sont convenues de désigner cette institution permanente d'arbitrage en considération du règlement par elles connu sans stipuler une soumission au règlement en vigueur à la date d'introduction de la procédure d'arbitrage, aucune disposition du règlement de 1988, en vigueur en 1993, ne prévoyant que la version du règlement applicable serait celle de la date de mise en œuvre de l'arbitrage».

${ }^{18}$ Ibid.

${ }^{19}$ Offshore International c. Banco Central (1976), 2 Lloyd's Law Reports, pág. 407: "[I]f the parties had wanted to provide for the 1955 rules to be the rules that were applicable to any arbitration that took place between them they could have so provided». 
interesante reflexión acerca de las diferencias entre las disposiciones sustantivas del acuerdo y aquellas otras de naturaleza procedimental, para concluir que la versión reformada del reglamento resultará aplicable en relación con los aspectos procedimentales ${ }^{20}$. En cambio, en el caso Mertens c. Veevoeder (1979), el juez concluyó que la antigua versión del reglamento había quedado incorporada de forma estática al convenio arbitral porque la cláusula arbitral contenía la expresión «forma parte de este contrato» ${ }^{21}$. En el asunto Cremer c. Granaria (1981), el último de esta serie de casos, el juez entendió que no era razonable esperar de los árbitros que comprobasen la fecha del convenio arbitral para aplicar una versión antigua del reglamento vigente en esa fecha ${ }^{22}$.

${ }^{20}$ Bunge c. Kruse (1979), 1 Lloyd's Law Reports, pág. 279: «There is, as it seems to me, a difference between a clause incorporating a code containing mainly substantive provisions, i.e. provisions defining or affecting the substantive rights of the parties, on the one hand, and a clause incorporating a code containing mainly procedural provisions, i.e. provisions laying down the procedure to be followed in the arbitration of disputes, on the other hand. In the case of the first kind of clause, of which the provision in the present contract incorporating GAFTA form 100 is an example, it is clear that the code incorporated is that contained in form 100 as existing and in force at the date of the contract. In the case of the second kind of clause, of which cl. 30(a) of GAFTA 100 incorporating the arbitration rules in GAFTA 125 is an example, the prima facie inference, I think, is that the code incorporated is that in force when the time for invoking and acting on the procedural provisions concerned arises. In support of this view it can be said that the other view could lead to considerable difficulties. Procedural provisions can easily become out of date and so become incapable of implementation. For instance, procedural rules might provide for documents to be sent to, or hearings to take place at, an address which later ceased to be appropriate or even to exist; or for members of a tribunal to possess a qualification, or to be appointed by a person holding an office, which is subsequently abolished. In either case amendment of the procedural rules concerned would be necessary to make them workable, and, if a clause incorporating such rules were not construed as incorporating them in their subsequently amended form, the operation of the clause might well be frustrated».

${ }^{21}$ Mertens c. Veevoeder (1979) 2 Lloyd's Law Reports, pág. 372: «The question is essentially one of construction turning on cl. 30(a) of form 100. That provides: 'Any dispute arising out of or under this contract shall be settled by arbitration in London in accordance with the Arbitration Rules of the Grain and Feed Trade Association Limited, No. 125, such Rules forming part of this contract and of which both parties hereto shall be deemed to be cognisant.' It seems to me that the rules which are thereby incorporated are the rules in force at the time of the contract. That is the natural meaning of the clause, subject only to the possibility of subsequent amendment, which I shall mention in a moment. Certainly, cl. 30 should not be read as incorporating rules which had ceased to be in force before the date of the contract. The test must be what the parties would have been told if they had made an enquiry of the association on the day of the contract. If that is the right test, as I believe it to be, then there can be no doubt as to the answer since it is clearly set out in the award in para. 34(d)».

${ }^{22}$ Cremer c. Granaria (1981) 2 Lloyd's Law Reports, pág. 583: «[I]f one looks at it as a matter of commonsense, I do not think it can be expected that arbitrators in any particular case should have to look at the date of the contract, ascertain the relevant 
En el caso China Agribusiness Development Corp. c. Balli Trading (1998), las partes acordaron someter sus controversias a arbitraje en la Foreign Economic and Trade Arbitration Commission (FETAC) del China Council for the Promotion of International Trade de acuerdo con su reglamento. Cuando se inició el procedimiento arbitral, la FETAC había cambiado su denominación por China International Economic and Trade Arbitration Commission (CIETAC) y el reglamento de la FETAC había dejado de existir. CIETAC aceptó la solicitud de arbitraje y envió una copia de su reglamento al demandado, que no compareció. El procedimiento arbitral continuó con arreglo al reglamento de la CIETAC. Más adelante, en el procedimiento de reconocimiento y ejecución del laudo arbitral en Inglaterra, el demandado alegó que el procedimiento arbitral no había seguido el acuerdo de las partes. Aunque el demandado reconoció que la CIETAC era sucesora de la FETAC, sostuvo que había acordado expresamente someterse al reglamento de la FETAC. La sentencia concluye, sin embargo, que el laudo era ejecutable porque, conforme al Derecho inglés, si un convenio arbitral exige que un procedimiento arbitral se rija por el reglamento de una institución en concreto, «ese acuerdo se refiere prima facie al reglamento en vigor al tiempo en que el arbitraje comienza ${ }^{23}$.

En el caso Kaneria c. England and Wales Cricket Board Ltd (ECB) (2014), un jugador paquistaní de cricket firmó un contrato con el Essex Cricket Club por el que se sometió a los «Reglamentos, Regulaciones, Directivas y Resoluciones» de la England and Wales Cricket Board "en vigor» ${ }^{24}$. Las Reglas de la Comisión Disciplinaria de Cricket de 2009, aplicables cuando el demandante suscribió el contrato, fueron modificadas en 2012, antes de que se iniciara el procedimiento. De acuerdo con las reglas de 2009, la máxima condena en costas era de 2.000 libras. Sin embargo, la versión de 2012 no establecía ningún límite cuantitativo en materia de costas. El tribunal arbitral consideró que las reglas de 2012 eran aplicables por dos motivos: primero, porque, tratándose de normas procedimentales, cabe esperar que se apliquen aquellas en vigor en el momento del inicio del procedimiento; y

procedure for arbitrations which were in force as at that date and then, regardless of the fact that new procedures, which may or may not be fundamental, may have been introduced as applicable (...) at the date when the arbitrators were appointed, (...) apply the old procedure in force as at the date when the contract was made».

${ }^{23}$ China Agribusiness Development Corp. c. Balli Trading (1998) 2 Lloyd's Law Reports, pág. 733: «As a matter of English law it is clear that if an arbitration agreement requires an arbitration to be held according to the rules of a particular institution, that agreement prima facie refers to the rules current at the time when the arbitration is begun».

${ }^{24}$ En el original en inglés, "for the time being in force» (Kaneria c. England and Wales Cricket Board Ltd [2014] EWHC 1348 [Comm]). 
segundo, porque considera que cuando el demandante se comprometió a cumplir las normas «en vigor» consintió la aplicación de las normas vigentes en cada momento.

\subsubsection{Italia}

A diferencia de las demás jurisdicciones analizadas en el presente trabajo, la solución que el ordenamiento jurídico italiano ofrece para esta cuestión se encuentra en su lex arbitri. El artículo 832.3 del Codice di procedura civile establece que si las partes no hubieran acordado otra cosa, se aplicará «el reglamento en vigor en el momento en que comienza el procedimiento arbitral ${ }^{25}$.

Por tanto, si las partes desean arbitrar sus disputas en Italia bajo la versión del reglamento de arbitraje vigente al tiempo de la suscripción del convenio arbitral, no cabe duda de que deben indicarlo específicamente. De otro modo, se aplicará la regla supletoria establecida legalmente ${ }^{26}$.

\subsubsection{Suiza}

En el caso Komplex c. Voest Alpine Stahl (1990), las partes habían suscrito un contrato en 1980 que incluía un convenio de sumisión a arbitraje de la CCI sin especificar el reglamento aplicable.

En el caso CCI núm. 5622, se dictó un primer laudo en 1988, que fue anulado por los tribunales suizos. Tras la anulación, en 1990 fue nombrado un nuevo árbitro en sustitución del anterior. El artículo 2.12 de la nueva versión del reglamento de la CCI aprobada en 1988 permitía al nuevo árbitro decidir si las anteriores actuaciones llevadas a cabo ante el primer árbitro debían repetirse. En 1992 el árbitro dictó laudo final en el que consideró aplicable el reglamento de 1988 porque no modificaba las bases del procedimiento arbitral de la CCI ni aprobaba nuevas disposiciones que pudieran sorprender a las partes. Este segundo laudo fue nuevamente impugnado.

El Tribunal Federal suizo confirmó la validez del laudo al considerar también aplicable la nueva versión del reglamento. En su deci-

25 «Se le parti non hanno diversamente convenuto, si applica il regolamento in vigore al momento in cui il procedimento arbitrale ha inizio".

${ }^{26}$ Emanuele, Ferdinando y Molfa, Milo, en Selected Issues in International Arbitration: The Italian Perspective, Thomson Reuters 2014, págs. 91 y 92. 
sión, el Tribunal Federal tuvo en cuenta que, dadas las circunstancias, incluso si las partes hubiesen conocido la versión reformada del reglamento, habrían acordado la misma cláusula de arbitraje ${ }^{27}$.

El Tribunal Federal suizo establece así que, en principio, la remisión a un reglamento arbitral se entenderá hecha a las disposiciones reglamentarias vigentes al comienzo del arbitraje. Sin embargo, parece introducir a contrario sensu un relevante matiz: el reglamento reformado podría ser inaplicado si las partes no hubieran consentido esa nueva versión.

\subsubsection{Singapur}

Durante los últimos años esta cuestión se ha planteado con cierta frecuencia en los tribunales de Singapur, una de las principales sedes de arbitraje del continente asiático. La solución adoptada reiteradamente en esos casos, con una fuerte inspiración en los precedentes ingleses, ha sido la de conferir al convenio arbitral un carácter dinámico.

En el caso Car \& Car c. Volkswagen A. G. (2009), el convenio arbitral, suscrito antes de que entrase en vigor el reglamento de 2007 del Singapore International Arbitration Centre (SIAC), sometía sus disputas a arbitraje del SIAC "de acuerdo con el Reglamento en vigor» ${ }^{28}$. En el procedimiento se discutió si la expresión «en vigor» se refería al momento de la suscripción del convenio o al comienzo del procedimiento de arbitraje. La resolución considera que el empleo de esa expresión apunta a un reglamento que no puede ser identificado con precisión en el presente, pues si se hubiera pretendido hacer referencia a las normas existentes a la fecha del contrato, no habría sido necesario recurrir a palabras generales ${ }^{29}$.

${ }^{27}$ Tribunal Fédéral, 1ére Cour civile, 14 de junio de 1990, Komplex c. Voest-Alpine Stahl: «Die Schiedsabrede wurde (...) in Form einer Schiedsklausel (...) geschlossen, eingefügt in einen bedeutenden Wirtschaftsvertrag, von dem mit gutem Grund anzunehmen ist, dass ihn vernünftige Partner auch abgeschlossen hätten, wenn sie gewusst hätten, dass das Schiedsgericht nach der Demission eines Schiedsrichters selbst bestimmen kann, welche Verfahrensabschnitte durch das neu besetzte Gericht zu wiederholen sind».

${ }^{28}$ En el original: «in accordance with the Rules of the Singapore International Arbitration Centre for the time being in force».

${ }^{29}$ Car \& Cars Pte Ltd c. Volkswagen AG (2009), Singapore High Court: "As a matter of construction, it may be fairly argued that the employment of general phraseology referring to rules «for the time being in force» points to rules that presently cannot be precisely identified. Were the intention to refer to rules existing at the date of the 
En la misma línea, en el caso Black \& Veatch Singapore Pte. Ltd. c. Jurong Engineering Ltd. (2003) el High Court indicó que si las partes acuerdan remitirse al reglamento de una institución arbitral en particular, sin especificar un reglamento en concreto, el reglamento aplicable será el que estuviera vigente en el momento del comienzo del arbitraje, con independencia de si se trata de una nueva versión reformada o incluso de un reglamento totalmente diferente ${ }^{30}$.

En el caso $A Q Z$ c. ARA (2015), la disputa se refería a un contrato suscrito en enero de 2010, por el que las partes sometían sus disputas a arbitraje «de acuerdo con el reglamento de mediación y arbitraje del SIAC por tres árbitros». En 2010 entró en vigor un nuevo reglamento del SIAC que preveía un procedimiento arbitral abreviado con un único árbitro. En el año 2013, una de las partes inició ante el SIAC un arbitraje abreviado con un árbitro único. El demandado instó la anulación del laudo dictado por el árbitro, alegando que el reglamento vigente cuando las partes contrataron era el reglamento del SIAC de 2007, que no contemplaba un procedimiento abreviado y que las partes habían acordado expresamente que el arbitraje fuera resuelto por tres árbitros. El Tribunal desestimó la acción anulatoria, considerando -en un caso que podríamos calificar de extremo- que el procedimiento arbitral se había tramitado conforme al acuerdo de las partes porque la disposición reglamentaria reguladora del procedimiento abreviado con un árbitro único puede dejar sin efecto el acuerdo de las partes sobre el arbitraje con tres árbitros, incluso cuando el contrato se hubiera celebrado antes de que entrara en vigor el nuevo reglamento ${ }^{31}$.

\subsection{La tendencia comparada hacia una interpretación dinámica del convenio arbitral}

Del análisis anterior se desprende que, en ausencia de concreción por las partes, la experiencia comparada ofrece de forma consistente

contract, there would not have been need for the general words. The particular set of rules could easily have been identified by name».

${ }^{30}$ Jurong Engineering Ltd c. Black \& Veatch Singapore Pte Ltd (2003), Singapore High Court: «[O]nce parties had agreed to adopt the rules of a particular arbitral institution, without specifying the particular set of rules, the applicable rules would be those that were current at the time of submission to arbitration, regardless of whether we were dealing with a new amended version, or an entirely different set of rules».

${ }^{31}$ AQZ c. ARA (2015), Singapore High Court: «[T]he Expedited Procedure provision can override parties' agreement for arbitration before three arbitrators even when the contract was entered into before the Expedited Procedure provision came into force». 
una solución favorable a la aplicación del reglamento vigente al tiempo del inicio del procedimiento arbitral. Por ello se ha dicho que la regla general en el arbitraje internacional es que el reglamento aplicable será aquel en vigor en el momento del arbitraje, salvo pacto en contrario de las partes ${ }^{32}$. Esa regla general ha sido también formulada en forma de presunción iuris tantum en favor de la aplicación del reglamento en vigor al comienzo del arbitraje ${ }^{33}$.

\section{LA REFORMA DE LOS REGLAMENTOS DE ARBITRAJE Y SU IMPACTO SOBRE EL CONVENIO ARBITRAL EN ESPAÑA}

En la lex arbitri española, la libertad de las partes de un convenio arbitral para seleccionar las reglas procedimentales aplicables a sus eventuales disputas se encuentra reconocida en el artículo 25.1 de la LA. De esta forma, las partes pueden expresar su acuerdo acerca de cómo desean que se desarrolle el eventual procedimiento arbitral. Los árbitros deben respetar la elección de las partes y, sólo a falta de acuerdo sobre las normas de procedimiento aplicables, entrará en juego su amplia potestad de dirección prevista en el párrafo segundo del mismo artículo 25 de la LA.

En particular, si las partes han decidido hacer uso de esa facultad a través de la sumisión a un reglamento, el artículo 4.b de la LA establece que se entenderá que las disposiciones de ese reglamento integran el contenido del convenio arbitral ${ }^{34}$.

La calificación de tal reenvío es, como han indicado nuestros tribunales, la de un negocio jurídico per relationem ${ }^{35} \mathrm{o}$, como señala la

${ }^{32}$ Verbist, Herman, "Cepani (Belgian Centre for Arbitration and Mediation) Modifies its Rules», Arbitration International, 2001, Volumen 17, pág. 99.

${ }^{33}$ Greenberg, Simon y Mange, Flavia, op. cit. supra n. 8, págs. 199 a 213.

${ }^{34}$ De acuerdo con el artículo 4 de la LA: «Cuando una disposición de esta ley: (...) b) Se refiera al convenio arbitral o a cualquier otro acuerdo entre las partes, se entenderá que integran su contenido las disposiciones del reglamento de arbitraje al que las partes se hayan sometido». Para HernándEz-GIL, la solución al problema aquí planteado se encuentra en este precepto: «Con esta regla de interpretación normativa, las disposiciones reglamentarias del tiempo en que se proceda a la aplicación de la Ley 60/2003 integran el convenio arbitral» (HERNÁNDEZ-GIL ÁlvAREZ-CIENFUEGOS, Antonio, en De Martín Muñoz, Alberto y Hierro AnIBarro, Santiago (coords.), op . cit. supra n. 7, pág. 187). Si bien compartimos esta conclusión, consideramos que de la redacción del artículo 4 de la LA no se desprende la integración de reglamento «del tiempo en que se proceda a la aplicación de la Ley 60/2003».

${ }^{35}$ Así lo indican el Auto de la Audiencia Provincial de Madrid (Sección 14. a) de 19 de abril de 2007 (Roj: AAP M 5076/2007) y la Sentencia de la Audiencia Provincial de Madrid (Sección 11. ${ }^{\text {) }}$ ) de 27 de diciembre de 2011 (Roj: SAP M 19365/2011). 
propia exposición de motivos de la LA, la de un «contrato normativo» ${ }^{36}$. A continuación se abordará el estudio del efecto de las reformas del reglamento de remisión sobre el convenio arbitral desde esta doble perspectiva.

\subsection{El convenio arbitral con remisión a un reglamento como negocio jurídico per relationem}

El convenio arbitral que contiene una remisión a un reglamento de arbitraje es un negocio jurídico per relationem, es decir, un «negocio perfecto e incompleto, en el que la determinación de su contenido o de algunos de sus elementos esenciales se realiza mediante la remisión a elementos extraños al mismo» ${ }^{37}$. Se trata de un caso de heterointegración contractual ${ }^{38}$, en el que se hace necesario analizar si cuando la relatio -el elemento externo de reenvío- es susceptible de modificación, el contrato evoluciona con ella o, por el contrario, debe entenderse que la remisión se realiza únicamente a ese elemento extraño tal y como se encuentra en el momento del reenvío.

La llamada interpretación evolutiva o dinámica ${ }^{39}$ ha sido ampliamente estudiada en el ámbito del derecho internacional público en

${ }^{36}$ Exposición de Motivos, II: «El artículo 4 contiene una serie de reglas de interpretación, entre las que tienen especial relevancia las que dotan de contenido a las normas legales dispositivas de esta ley mediante la remisión, por voluntad de las partes, a la de una institución arbitral o al contenido de un reglamento arbitral. Así, esta ley parte en la mayoría de sus reglas de que debe primar la autonomía de la voluntad de las partes. Mas esa voluntad se entiende integrada por las decisiones que pueda adoptar, en su caso, la institución administradora del arbitraje, en virtud de sus normas, o las que puedan adoptar los árbitros, en virtud del reglamento arbitral al que las partes se hayan sometido. Se produce, por tanto, una suerte de integración del contenido del contrato de arbitraje o convenio arbitral, que, por mor de esta disposición, pasa a ser en tales casos un contrato normativo».

${ }^{37}$ Díaz-Ambrona BaRdaJI, M. ${ }^{a}$ Dolores, El negocio jurídico "per relationem» en el Código Civil, Colex 1982, pág. 42. La autora precisa que «[p]ara que surja la relatio es inexcusable la existencia de un negocio perfecto. Y en cuanto hecho, no supone que sea posterior al negocio en el tiempo, ya que puede consistir en un evento presente, pasado o futuro» (pág. 30).

${ }^{38}$ Se ha dicho que "[l]o dispuesto en la letra «b)» de este art. 4 LA concuerda con la norma general de integración de los contratos contenida en el art. 1.258 CC» (Prats Albentosa, Lorenzo (coord.), Comentarios a la Ley de Arbitraje, La Ley 2013, pág. 151). Consideramos, sin embargo, que en este caso la integración del convenio arbitral no se produce por la remisión legal «a la buena fe, al uso y a la ley» (art. $1.258 \mathrm{CC}$ ), sino con base en lo expresamente pactado por las partes que deciden someterse a un reglamento arbitral.

${ }^{39}$ Según Malgosia Fitzmaurice los conceptos de interpretación «evolutiva» y «dinámica» son sinónimos (Fitzmaurice, Malgosia, «The Practical Working of the Law of Treaties», en Evans, Malcolm D. (ed.), International Law, 3. ${ }^{a}$ ed., Oxford University 
relación con el análisis hermenéutico de los tratados internacionales. Aunque el denominado "principio de contemporaneidad» o de interpretación estática ha sido tradicionalmente aceptado como una de las nociones de la interpretación de los tratados ${ }^{40}$, la doctrina mayoritaria ha considerado que la interpretación dinámica es admisible para la exégesis de ciertos términos de un tratado expresados de un modo tan general que se prestan a una interpretación evolutiva ${ }^{41}$. Thirlway acuñó el término "remisión intertemporal» (intertemporal renvoi) para referirse precisamente a la situación que surge cuando la intención de las partes fue someter las relaciones jurídicas creadas a la norma vigente en cada momento ${ }^{42}$. Esa remisión, como ha señalado el propio profesor Thirlway más recientemente ${ }^{43}$, puede hacerse tanto a un elemento normativo como a una circunstancia fáctica, siendo idénticos los efectos del reenvío en ambos casos.

Aunque se ha considerado que la interpretación dinámica o evolutiva es uno de los aspectos «más polémicos, controvertidos y discutidos en la interpretación de los tratados ${ }^{44}$, lo cierto es que los tribunales internacionales han acogido este recurso exegético, anudando frecuentemente la interpretación dinámica o evolutiva a la naturaleza genérica de los términos empleados por las partes.

El Tribunal Internacional de Justicia de la Haya consideró en la opinión consultiva del caso Namibia (1971) que los términos formulados de modo general o abierto «no son estáticos, sino evolutivos por definición ${ }^{45}$. En el mismo sentido, en el fallo del caso de la Plataforma Continental del Mar Egeo (1978), el Tribunal concluyó que el signi-

Press 2010, pág. 188). Esta misma terminología se ha empleado también para referirse al problema objeto del presente estudio (vid. MüLLER-CHEN, Markus y PAIR, Lara M, "Commentary on the Swiss Rules», en Arroyo, Manuel (ed.), Arbitration in Switzerland: The Practitioner's Guide, Kluwer Law International 2013, pág. 340).

${ }^{40}$ Fitzmaurice, Gerald, "The Law and Procedure of the International Court of Justice 1951-4: Treaty Interpretation and Other Points», British Yearbook of International Law, núm. 33, 1957, pág. 212: «The terms of a treaty must be interpreted according to the meaning which they possessed, or which would have been attributed to them, and in the light of current linguistic usage, at the time when the treaty was originally concluded».

${ }^{41}$ SinClaIR, Ian, The Vienna Convention on the Law of Treaties, 2. ${ }^{\text {a }}$ ed., Manchester University Press 1984, pág. 140.

${ }^{42}$ ThIRlwaY, Hugh, "The Law and Procedure of the International Court of Justice 1960-1989: Part One», British Yearbook of International Law, núm. 60, 1989, pág. 135.

${ }^{43}$ THIRLwaY, Hugh "The Law and Procedure of the International Court of Justice 1960-1989: Supplement 2006: Part Three», British Yearbook of International Law, núm. 77, 2006, pág. 67.

${ }^{44}$ FitzMaurice, Malgosia, op cit. supra n. 39, pág. 188.

${ }^{45}$ Opinión consultiva de 21 de junio de 1971 dictada por el Tribunal Internacional de Justicia en el Caso relativo a las consecuencias jurídicas que tiene para los Estados 
ficado de una expresión genérica se corresponde «con el significado que se le atribuye a la expresión en la ley vigente en cada momento», de modo que el significado de un término genérico está «destinado a seguir la evolución de la ley» ${ }^{46}$. Y, en fin, en el fallo del caso sobre $D e$ rechos de Navegación y Derechos Conexos (2009), «cuando las partes han usado términos genéricos en un tratado, sabiendo que probablemente evolucionaría el significado de los términos con los años, y cuando el tratado se concluyó hace mucho tiempo o es 'de duración continuada', cabe suponer que las partes, como norma general, tenían la intención de que el significado de dichos términos pudiera evolucionar ${ }^{47}$. El Tribunal formuló así una regla general, estableciendo que debe presumirse una intención evolutiva cuando concurran los siguientes presupuestos: (i) que las partes hayan utilizado «términos genéricos» (en cuyo caso las partes «necesariamente han tenido conocimiento de que es probable que el significado de los términos evolucionen con el tiempo»); y (ii) que el tratado se haya celebrado durante un tiempo muy largo o sea «de duración continuada» ${ }^{48}$.

Aunque en ocasiones se ha formulado esta regla interpretativa con carácter excesivamente general ${ }^{49}$, no debe perderse de vista que se

la continuación de la presencia de Sudáfrica en Namibia (África Sudoccidental), no obstante lo dispuesto en la Resolución 276 (1970) del Consejo de Seguridad.

${ }^{46}$ Fallo de 19 de diciembre de 1978 dictado por el Tribunal Internacional de Justicia en el Caso relativo a la plataforma continental del Mar Egeo (Grecia c. Turquía).

${ }^{47}$ Fallo de 13 de julio de 2009 dictado por el Tribunal Internacional de Justicia en la Causa relativa a la controversia sobre derechos de navegación y derechos conexos (Costa Rica c. Nicaragua).

${ }^{48}$ Esta regla general ha sido aplicada por otros tribunales internacionales. Por ejemplo, el tribunal arbitral de la Corte Permanente de Arbitraje en el caso sobre el Rin de Hierro (2005) aplicó una interpretación dinámica para tener en cuenta los últimos avances en derecho medioambiental desde la suscripción del tratado analizado entre Bélgica y Países Bajos en 1839, razonando que: «It has long been established that the understanding of conceptual or generic terms in a treaty may be seen as 'an essentially relative question; it depends upon the development of international relations' (...) Some terms are 'not static, but were by definition evolutionary'» (laudo de 24 de mayo de 2005 dictado en el caso Rin de Hierro (Bélgica/Países Bajos), §79 -disponible en www.pca-cpa.org-). En el mismo sentido, el Panel del Tratado de Libre Comercio de América del Norte en el Caso con respecto a los aranceles aplicados por Canadá a ciertos productos agropecuarios originarios de Estados Unidos: "[L]a referencia al GATT [Acuerdo General sobre Aranceles Aduaneros y Comercio] y los acuerdos negociados en el marco del GATT deben haber hecho referencia al GATT no como un texto de derecho fijo sino como uno capaz de evolucionar [...] Esto, le parece al Panel, es la esencia del argumento de Canadá en el sentido de que la referencia al GATT en el Artículo 710 del ALC [Acuerdo de Libre Comercio] se debería entender como una referencia a un 'sistema legal en evolución'» (Informe Final del Panel, Expediente del Secretariado núm. CDA-95-2008-01, 2 de diciembre de 1996, §§137 y 138).

${ }^{49}$ ClasmeIER, Maximilian, Arbitral Awards as Investments: Treaty Interpretation and the Dynamics of International Investment Law, International Arbitration Law Library, 
trata simplemente de una concreción del principio general que debe presidir todo proceso hermenéutico: la averiguación de la intención de las partes ${ }^{50}$. Es decir, la interpretación dinámica no ha sido aceptada en aquellos casos en que, aunque el significado de las palabras empleadas había cambiado, existían elementos que descartaban que las partes hubieran tenido la intención de que esos términos evolucionaran ${ }^{51}$. En cualquier caso, esa intención de las partes consistente en dejar determinadas cuestiones abiertas a posibles cambios extrínsecos no puede confundirse con el hecho de que esas modificaciones fueran predecibles. Las disposiciones dinámicas evolucionan -de acuerdo con la intención de las partes-, pero pueden hacerlo de un modo que las partes no hayan podido predecir ${ }^{52}$.

Siguiendo en el ámbito del derecho internacional público, estas nociones han sido aplicadas en procedimientos arbitrales para la protección de inversiones para concluir la aplicabilidad de reglamentos de arbitraje reformados entre la ratificación del tratado en cuestión y el inicio del procedimiento. En el reciente arbitraje Evrobalt LLC (Rusia) c. República de Moldavia (2016) administrado por la Cámara de Comercio de Estocolmo, se interpretó de forma dinámica el artículo 10 del Tratado Bilateral de Inversión entre la Federación Rusa y Moldavia, según el cual cualquier controversia se somete genéricamente «a la consideración del Instituto de Arbitraje de la Cámara de Comercio de Estocolmo» ${ }^{53}$. El tratado había sido firmado en 1998 y ratifica-

Volume 39, Kluwer Law International 2016, pág. 9: «The terms of an international treaty are thus dynamic, unless the signatories expressly intended otherwise»

${ }^{50}$ Higgins, Rosalyn, "Some Observations on the Inter-Temporal Rule in International Law», in MAKARCZYK, Jerzy (ed.), Theory of International Law at the Threshold of the 21st Century, Kluwer Law International 1996, pág. 181: «[G]eneric clauses' (...) are not really random exceptions to a general rule (...) [but] an application of a wider principle -intention of the parties, reflected by reference to the object and purposethat guides the law of treaties».

${ }^{51}$ Por ese motivo, el Tribunal Internacional de Justicia ha negado en ocasiones la aplicación de una interpretación dinámica (vid. fallo de 27 de agosto de 1952 en el Caso relativo a los derecho de los nacionales de los Estados Unidos de América en Marruecos y fallo de 13 de diciembre de 1999 en el Caso relativo a la isla de Kasikili/Sedudu [Botswana c. Namibia]).

${ }^{52}$ Helmersen, Sondre Torp, «Evolutive Treaty Interpretation: Legality, Semantics And Distinctions», European Journal of Legal Studies, Volumen 6, 2013, pág. 172.

${ }^{53}$ Laudo de 30 de mayo de 2016 sobre medidas cautelares, Arbitraje de Emergencia núm. 2016/082 del Instituto de Arbitraje de la Cámara de Comercio de Estocolmo (Evrobalt LLC (Rusia) c. República de Moldavia). El laudo cita también la resolución de 18 de mayo de 2009 dictada por un tribunal sueco -el Tribunal de Apelación de Svea- en el caso Auto Connect Sweden A. B. c. Consafe. Esa sentencia, aplicando Derecho sueco, acoge también una concepción dinámica del convenio arbitral, al concluir que el actual reglamento de la Cámara de Comercio de Estocolmo era aplicable a un arbitraje iniciado después de la fecha de entrada en vigor de las nuevas disposi- 
do por Moldavia el propio 1998 y por Rusia en el año 2001. La versión del Reglamento de la Cámara de Comercio de Estocolmo existente en el momento de la firma del Tratado no preveía un procedimiento de emergencia. Este procedimiento fue incluido en el reglamento de la Corte en el año 2010. No obstante lo anterior, «la referencia al arbitraje de la Cámara de Comercio de Estocolmo en el mismo [artículo] debe interpretarse como una referencia dinámica a la versión del Reglamento de la Cámara de Comercio de Estocolmo vigente en el momento del inicio del arbitraje» ${ }^{54}$.

Estas consideraciones son plenamente trasladables al Derecho nacional español, pues hallan perfecto acomodo en los cánones interpretativos de nuestro Derecho de contratos. Como se ha indicado, la interpretación dinámica no es más que una pauta exegética que concreta el principio rector de la labor hermenéutica, esto es, la averiguación de la voluntad efectivamente querida por las partes ${ }^{55}$ a través de la literalidad del texto contractual, que constituye el criterio interpretativo de rango preferencial y prioritario ${ }^{56}$.

Frente a esta interpretación podría objetarse que la aplicación del reglamento reformado puede someter a las partes a disposiciones procedimentales que no conocían al tiempo de contratar y que, al poder restringir o modificar facultades procedimentales, las partes tienen interés en "saber a ciencia cierta qué procedimiento va a regir su controversia futura ${ }^{57}$. Aunque se refiere a un caso distinto al que aquí se analiza, esta es la idea que late tras el Auto de la Audiencia Provincial de Madrid (Sección 14. ${ }^{a}$ ) de 19 de abril de 2007, que se refiere a un reglamento "cuyas disposiciones, por no existir tal reglamento en el momento de celebrar el convenio arbitral, no podían, ni pueden integrar la voluntad de las partes» ${ }^{58}$.

ciones reglamentarias, aunque el reglamento fuera reformado después de que las partes firmaran el convenio arbitral.

${ }^{54}$ En el mismo sentido y sobre el mismo tratado, vid. el más reciente laudo de 14 de junio de 2016 sobre medidas cautelares, Arbitraje de Emergencia núm. 2016/095 del Instituto de Arbitraje de la Cámara de Comercio de Estocolmo (Kompozit LLC (Rusia) c. República de Moldavia).

${ }^{55} \mathrm{Al}$ respecto y por todas, puede citarse la Sentencia de la Sala Primera del Tribunal Supremo de 7 de octubre de 2016 (Roj: STS 4288/2016): «[D]ebe destacarse que en el proceso interpretativo de los contratos la averiguación o búsqueda de la voluntad real o efectivamente querida por las partes se erige como principio rector de la labor interpretativa, de forma que las demás reglas confluyen a su alrededor bien complementándola, bien supliéndola, pero nunca limitándola o alterándola».

${ }^{56}$ Art. 1.281.1. ${ }^{\circ}$ CC.

${ }^{57}$ FernÁnDEZ-RozAS, José Carlos, op. cit. supra n. 1, pág. 81: «el interés de las partes de saber a ciencia cierta qué procedimiento va a regir su controversia futura».

${ }^{58}$ Roj: AAP M 5076/2007. 
Esta objeción, sin embargo, encierra un sofisma. Y es que es perfectamente posible, como se ha visto, que las partes presten su consentimiento sobre algún elemento del contrato cuyo concreto alcance desconocen en el momento de la perfección, postergando así a un momento ulterior la definitiva configuración del contrato. Además, en el momento de suscribir el convenio arbitral, las partes, aunque naturalmente no puedan conocer el contenido de futuras reformas del reglamento de remisión, sí conocen que el reglamento «actual» prevé que las normas aplicables al procedimiento arbitral serán las vigentes en el momento en que se inicie. Y, por otro lado, es razonable para las partes esperar que los reglamentos arbitrales sean reformados con cierta frecuencia, como han indicado tanto la doctrina ${ }^{59}$ como la práctica arbitral ${ }^{60}$. Por tanto, si no especifican que se remiten a una concreta versión del reglamento, debe entenderse que las partes dejaron deliberadamente abierta esta cuestión, poniéndose en manos de la institución arbitral -o de la entidad redactora del reglamento- asumiendo las consecuencias de eventuales cambios no conocidos en el momento de celebrar el negocio jurídico.

Este reenvío «en blanco» a un reglamento arbitral no debe ser entendido como un juego de azar de las partes del convenio arbitral. Con carácter general, las partes deciden remitirse a un sistema arbitral porque -ya sea por su reputación o por la previa experiencia de los contratantes- confían en ese sistema de un modo orgánico. Así, al seleccionar un reglamento, las partes no piensan necesariamente en sus concretas disposiciones, sino en la fiabilidad de ese sistema o institución arbitral ${ }^{61}$.

${ }^{59}$ Blackaby, Nigel, Partasides, Constantine y VV. AA., Redfern and Hunter on International Arbitration, 6th Edition, Oxford University Press 2015.

${ }^{60}$ Laudo interlocutorio de 30 de marzo de 1976 dictado en el caso núm. 2671 de la CCI: «We are unable to accept [A's] argument (...) that the parties, when they agreed to submit to ICC arbitration, could not possibly have contemplated ICC Rules other than those which were then in force. Why not? This alone was sufficient to put the parties on notice that the Rules which were in force on 1 June 1955 were not guaranteed to remain in force in aeternum. Moreover, the obviously very experienced lawyers who drafted the [agreement] could not have been ignorant of the fact that the ICC had been founded as far back as 1919 (a fact permanently stated on the inside cover of the 1955 set of Rules), that the institution of ICC arbitration had been in operation for many years before 1 June 1955, and that the 1955 set of Rules was in itself a consolidation and replacement of an earlier set».

${ }^{61}$ GreEnBERG, Simon y MANGE, Flavia, op. cit. supra n. 8, pág. 209: «It is technically sustainable because arbitration rules, although applicable contractually, are very different from negotiated contractual terms. The parties do not negotiate individual provisions of arbitration rules. They rather agree on a trusted system of arbitration or trusted institution. In choosing, say, the UNCITRAL or ICC Rules, parties are choosing those particular mechanisms but not necessarily the individual provisions of the rules. 


\subsection{El convenio arbitral con remisión a un reglamento como "contrato normativo"}

El régimen de la LA respecto de la integración del reglamento de arbitraje en el convenio arbitral es esencialmente coincidente con el recogido en la Ley Modelo ${ }^{62}$. Sin embargo, la Exposición de Motivos de la LA presenta una relevante singularidad al concebir el convenio arbitral que se remite a un reglamento como un "contrato normativo ${ }^{63}$.

La referencia de la Exposición de Motivos de la LA al contrato normativo tampoco ha recibido la atención de doctrina y jurisprudencia. Con carácter general, tanto la doctrina como la jurisprudencia se han limitado a reproducir el contenido del preámbulo de la LA, sin entrar a examinar el significado de semejante referencia. Considerando el valor jurídicamente cualificado de los preámbulos como pauta de interpretación ${ }^{64}$, se analizará a continuación el significado y alcance de esa mención contenida en la Exposición de Motivos de la LA.

La figura del contrato normativo es una construcción doctrinal que se ha empleado para describir realidades muy diversas, lo que ha valido para calificarlo de concepto "confuso» ${ }^{65}$.

En el plano del Derecho de contratos, los contratos normativos tienen como función fijar una reglamentación uniforme, general y

The metaphorical businessman is rarely interested in checking every single rule contained in a set of arbitration rules (if he checks any at all); he chooses the system and reputation of the institution as a whole. Save a contrary indication from the parties, it is irrelevant that individual provisions of the rules may change over time, or even that new, specialized sets of rules may evolve to complement the chosen rules».

${ }^{62}$ Art. 2.e) de la Ley Modelo sobre Arbitraje Comercial Internacional de la CNUDMI: «cuando una disposición de la presente Ley se refiera a un acuerdo que las partes hayan celebrado o que puedan celebrar o cuando, en cualquier otra forma, se refiera a un acuerdo entre las partes, se entenderán comprendidas en ese acuerdo todas las disposiciones del reglamento de arbitraje en él mencionado».

${ }^{63}$ Vid. supra n. 36.

${ }^{64}$ Según el Tribunal Constitucional, los preámbulos y exposiciones de las leyes gozan de una "cualificada condición como criterio hermenéutico», en la medida en que, "por tratarse de la expresión de las razones en las que el propio legislador fundamenta el sentido de su acción legislativa y expone los objetivos a los que pretende que dicha acción se ordene, constituye un elemento singularmente relevante para la determinación del sentido de la voluntad legislativa, y, por ello, para la adecuada interpretación de la norma legislada» (Sentencia 31/2010 del Pleno, de 28 de junio, BOE núm. 172, de 16 de julio de 2010; en el mismo sentido, vid. la Sentencia 36/1981 del Pleno, de 12 de noviembre, BOE núm. 277, de 19 de noviembre de 1981).

${ }^{65}$ O'Callaghan Muñoz, Xavier y Pedreira Andrade, Antonio, Introducción al derecho y derecho civil patrimonial, Editorial Centro de Estudios Ramón Areces, 1992, pág. 957. 
abstracta para que se acomoden a ella quienes deseen contratar en el futuro. Se trata de un pactum de modo contrahendi, por el que las partes contraen la obligación de contratar de cierto modo, caso de que, efectivamente, se quiera contratar ${ }^{66}$. También se han calificado como contratos normativos los acuerdos marco que se encargan de regular las concretas transacciones que puedan concertar los contratantes en el futuro ${ }^{67}$. Sin embargo, no es razonable pensar que la Exposición de Motivos de la LA conciba de esa manera el contrato normativo.

Otra acepción jurídica del contrato normativo se encuentra en el campo del Derecho laboral. Como ha indicado la doctrina, «el convenio colectivo es un contrato normativo o una norma contractual ${ }^{68}$. El convenio colectivo es, en efecto, una «norma» de origen convencional que vincula jurídicamente a personas que no han intervenido en su redacción. Así, los representantes de los trabajadores y de los empresarios pactan las condiciones de trabajo y, desde ese momento, las disposiciones del convenio «obligan a todos los empresarios y trabajadores incluidos dentro de su ámbito de aplicación y durante todo el tiempo de su vigencia» (art. 82.3 del Real Decreto Legislativo 2/2015, de 23 de octubre, por el que se aprueba el texto refundido de la Ley del Estatuto de los Trabajadores).

En este caso, pese a la enorme distancia que separa a los convenios colectivos de los reglamentos de arbitraje, sí pueden identificarse algunas notas comunes, que podrían haber llevado al legislador a emplear este escurridizo término en la Exposición de Motivos de la LA. Aunque de un modo diverso, el origen de la fuerza normativa de los reglamentos de arbitraje es también convencional y vinculan a personas que no han intervenido en su elaboración ni en sus eventuales reformas. Esta concepción reforzaría la idea de que, cuando las partes se remiten de forma genérica a un reglamento arbitral, las reformas que se produzcan en el reglamento vincularán a las partes, aunque no las hayan consentido de forma expresa.

${ }^{66} \mathrm{Vid}$. Auto de la Sala Primera del Tribunal Supremo de 27 de junio de 2006 (Roj: ATS 10650/2006). En el mismo sentido, vid. CASTÁn ToBeÑas, José, Derecho civil común y foral, Tomo III, Madrid 1978, pág. 476.

${ }^{67}$ Vid. Sentencia de la Sala Primera del Tribunal Supremo de 18 de noviembre de 2015 (Roj: STS 4919/2015).

${ }^{68}$ Alonso Olea, Manuel y Casas BaAmonde, María Emilia, Derecho del Trabajo, 25. ${ }^{a}$ ed., Civitas 2008, pág. 996. En el mismo sentido, Palomeque LóPez, Manuel Carlos, Derecho Sindical, 2. ${ }^{a}$ ed., Tecnos 1988, pág. 282: «El convenio es así, desde semejante óptica, una norma de origen contractual, una síntesis de norma y contrato, de fuente del derecho y fuente de la obligación, en fin, un contrato normativo». Ya CARNELUTTI se había referido al convenio colectivo como "un híbrido, que tiene el cuerpo del contrato y el alma de la ley» (CARNELUTTI, Francesco, Teoria del regolamento collettivo dei rapporti di lavoro, 1. a ed., Cedam 1928, pág. 108). 
En cualquier caso, sea cual sea el significado jurídico concreto de la expresión "contrato normativo", no cabe duda de que esos términos remiten, sin olvidar su origen convencional, a la esfera de lo normativo. Aunque naturalmente los reglamentos de arbitraje no constituyen verdaderas normas generales y abstractas ${ }^{69}$, la caracterización del convenio arbitral con remisión a un reglamento como un contrato normativo hace que cobre especial relevancia la naturaleza procedimental de esas «normas» de reenvío, pues sitúa la cuestión analizada en el ámbito de las reformas legislativas en materia procesal.

Esas modificaciones de la ley procesal, como ya expuso Chiovenda, son por su propia naturaleza de aplicación inmediata, en el sentido de que deben aplicarse en el litigio actual sin tener en cuenta el momento en que se ha desarrollado la relación que es objeto del litigio $^{70}$. El fundamento de este principio reside en que el Estado tiene interés en que la justicia sea administrada en el mejor modo y, a tal fin, introduce una nueva ley procesal a la cual los órganos judiciales deberán atenerse después de su entrada en vigor ${ }^{71}$.

En el ordenamiento procesal civil español este principio se encuentra recogido en el artículo 2 de la Ley 1/2000, de Enjuiciamiento Civil, conforme al cual «los asuntos que correspondan a los tribunales civiles se sustanciarán siempre por éstos con arreglo a las normas procesales vigentes, que nunca serán retroactivas». Quiere decirse con ello que, en la medida en que la relación procesal goza de autonomía respecto de la relación material, la primera debe regirse por la ley procesal vigente en el momento de su nacimiento, con independencia del momento en que se haya producido la segunda ${ }^{72}$. Si la aplicación

${ }^{69}$ Fernández-Rozas, José Carlos, op. cit. supra n. 1, pág. 84: «El Reglamento deriva, pues, de un acto de voluntad unilateral del centro arbitral, que desarrolla las normas legales sobre administración de arbitrajes, esto es, un conjunto de disposiciones de carácter privado cuya eficacia es exclusivamente inter partes; esto es, sólo desplegarán sus efectos respecto de aquéllos que se sometan al concreto centro de arbitraje solicitando el arreglo de su controversia. Por la razón expuesta los Reglamentos no constituyen normas de alcance general, limitándose a regular las relaciones de los particulares que se han sometido a los mismos».

${ }^{70}$ Chiovenda, Giuseppe, «La natura processuale delle norme sulla prova e l'efficacia della legge processuale nel tempo", Saggi di diritto processuale civile, vol I, Giuffrè, reed. 1993, pág. 243.

${ }^{71}$ Ibid.

${ }^{72}$ XIol Ríos, Juan Antonio, Enjuiciamiento civil. Comentarios y jurisprudencia. Ley 1/2000, de 7 de enero, Spein 2008, pág. 120. En el mismo sentido, De La Oliva Santos, Andrés, Díez-Picazo Giménez, Ignacio y Vegas Torres, Jaime, Derecho Procesal, Introducción, con, 2. ${ }^{a}$ ed., Ramón Areces 2001, pág. 135: «[L]a común irretroactividad general de las leyes sustantivas y de las procesales se refleja en una forma de aplicación distinta a la hora del proceso: la ley sustantiva aplicable en él puede estar derogada; la procesal, en cambio, siempre ha de estar vigente». 
de la ley procesal fuera dependiente de la fecha de nacimiento de la relación material se generarían, además, indeseables ineficiencias por la convivencia de leyes procesales distintas ${ }^{73}$.

En definitiva, esta idea -que, como se ha visto, aparece enunciada en la experiencia arbitral comparada como un principio de alcance general en relación con las normas procedimentales- adquiere en el ordenamiento español una singular relevancia, precisamente por la referencia de la Exposición de Motivos de la LA al contrato normativo.

\section{CONCLUSIONES}

La experiencia internacional muestra que, salvo en algún caso excepcional, existe una marcada preferencia por interpretar que las cláusulas que se remiten de forma genérica a un reglamento de arbitraje se refieren al reglamento vigente al tiempo del inicio del procedimiento arbitral.

El análisis de la lex arbitri española ofrece idéntica conclusión. Tanto si esta clase de convenios arbitrales se califican de negocios jurídicos per relationem como si se enmarcan dentro de la confusa categoría de los contratos normativos, es razonable concluir que, salvo que las partes hayan pactado algo distinto, resultará de aplicación el reglamento en vigor en el momento en que dé comienzo el procedimiento arbitral.

De cuanto se ha expuesto se pueden extraer conclusiones prácticas en relación con cada uno de los operadores jurídicos en el marco del arbitraje, empezando por el legislador, siguiendo con las instituciones arbitrales y las partes del convenio arbitral, para terminar con los árbitros y jueces que conozcan de esta materia:

(a) En primer lugar, el legislador español podría adoptar el modelo italiano, estableciendo en la LA una presunción legal en favor de la aplicación del reglamento de arbitraje en vigor en el momento del inicio del procedimiento.

(b) Desde la perspectiva de las instituciones arbitrales, es recomendable que, para evitar dudas, los reglamentos establezcan expre-

${ }^{73}$ Asimismo, como se ha apuntado desde la perspectiva de las instituciones arbitrales, la convivencia de distintas versiones del reglamento en función de la fecha de suscripción del convenio arbitral puede resultar ineficiente para la administración de los procedimientos arbitrales resucitar trámites y actuaciones pretéritos (CALVO CoRvella, Juan Carlos, en Ruiz Risueño, Francisco y Fernández Rozas, José Carlos [coords.], op. cit. supra n. 7, pág. 92). 
samente que, salvo pacto en contrario de las partes, las remisiones se entenderán hechas al reglamento vigente a la fecha de comienzo del arbitraje $^{74}$. Asimismo, las instituciones deben ser conscientes de que una modificación del reglamento aplicable retroactivamente podría frustrar las expectativas de las partes de convenios arbitrales ya suscritos, por lo que, al introducir cambios significativos en sus reglamentos pueden establecer mecanismos transitorios para evitar que esas reformas sorprendan a las partes ${ }^{75}$.

(c) Por otro lado, a la hora de redactar la cláusula de sumisión a arbitraje, las partes del convenio deben precisar a qué reglamento se refieren, siendo conscientes de que su silencio será interpretado como una remisión en blanco al reglamento en vigor en el momento en que se inicie el procedimiento arbitral.

(d) Por último, cuando las partes no hayan especificado en el convenio arbitral el reglamento aplicable, los árbitros -y eventualmente los jueces, en el procedimiento de anulación o reconocimiento- deben aplicar el reglamento vigente en cada momento.

${ }^{74}$ Así lo prevé el artículo 1.3 del Reglamento Modelo del Club Español del Arbitraje: «La sumisión al Reglamento de Arbitraje se entenderá hecha al Reglamento vigente a la fecha de comienzo del arbitraje, a menos que hayan acordado expresamente someterse al Reglamento vigente a la fecha del convenio arbitral» (Sección Segunda del Código de Buenas Prácticas Arbitrales del Club Español del Arbitraje de octubre de 2008, disponible en www.clubarbitraje.com).

${ }^{75}$ Esta sensibilidad se aprecia, por ejemplo, en la disposición incluida en el Reglamento de Arbitraje de la Cámara de Comercio Internacional que, al introducir la novedosa figura del Árbitro de Emergencia, precisa que «[1]as Disposiciones sobre el Árbitro de Emergencia no serán aplicables si: a) el acuerdo de arbitraje bajo el Reglamento fue concluido antes de la fecha en la cual el Reglamento entró en vigor». 
